\title{
Evaluation of Late Radiation Side Effects in Nasopharyngeal Cancer Patients
}

\author{
Alpaslan MAYADAGLI ${ }^{1}$, Gokhan YAPRAK ${ }^{1}$, Yılmaz TEZCAN ${ }^{2}$ \\ ${ }^{1}$ Dr. Lutfi Kirdar Kartal State Hospital, Department of Radiation Oncology, Istanbul, TURKEY \\ ${ }^{2}$ Selcuk University Meram Faculty of Medicine, Department of Radiation Oncology, Konya, TURKEY
}

\begin{abstract}
The prolongation of survival in cases with nasopharynx cancer has made quality of life after treatment more important. The aim of this study is to consider late toxicity developing after treatment in order to maintain a high quality of life. Thirty-two patients receiving radiotherapy (RT) to the neck region 1-10 years ago due to nasopharyngeal carcinoma were included in the study. Neck ultrasonography (USG), thyroid function tests and dynamic brain magnetic resonance imaging (MRI) were carried out for carotid artery stenosis, hypothyroidism, and necrosis of the temporal lobe. Obtained data were analyzed with the SPSS 11.5. Intima-media thickness of below 60 Gy and above 60 Gy doses administered to the neck were similar. Intima-media thickness was greater in patients with a period longer than 5 years after RT than with a period shorter than 5 years $(p<0.001)$. Intima-media thicknesses of the patients above 40 years, with high cholesterol values, a history of smoking and hypertension were higher than those without them $(p<0.001)$. There was hypothyroidism in five (15\%) of the 32 patients. Necrosis of the temporal lobe was not seen in any of the patients. Carotid artery stenosis after treatment depends more on the duration of the period after treatment and the patient's being in the age group when atherosclerotic risk factors are present than on the amount of dose administered.
\end{abstract}

Keywords: Head-neck tumor, Radiotherapy, Late toxicity, Hypothyroidism

\section{ÖZET}

\section{Nazofarenks kanserli Olgularda Rdyoterapiye Sekonder Gelişen Geç Yan Etkilerin Değerlendirilmesi}

Son yıllarda nazofarenks kanserli olgularda yaşam süresinin artması, tedavi sonrası yaşam kalitesini ön plana çıkarmıştır. Bu grup hastalarda yaşam kalitesini yüksek tutmak için tedavi sonrası gelişen geç toksisitelerin irdelenmesi amaçlanmıştır. Nazofarenks kanseri nedeniyle boyun bölgesine 1-10 yı önce radyoterapi (RT) alan 32 hasta çalışmaya alınmıştır. Hastaların karotis arter stenozu, hipotiroidi ve temporal lob nekrozu için boyun ultrasonogrofi (USG), tiroid fonksiyon testi ve dinamik beyin magnetik rezonansı (MR) yapımıştır. Elde edilen veriler SPSS 11.5'de değerlendirilmiştir. Boyuna uygulanan 60 Gy altı ile 60 Gy üzeri dozlardaki karotis intima-media kalınlığı benzer çıkmışır. RT sonrası geçen süre 5 yıldan fazla olan hastalarda intima-media kalınlığı, 5 yıldan az olan hastalara oranla daha yüksek saptanmıştır ( $p<0.001$ ). 40 yaş üstü, kolesterol değeri yüksek, sigara ve hipertansiyon hikayesi olan hastaların damar kalınlığı olmayanlardan daha yüksek çıkmıştır ( $p<0.001)$. 32 hastadan 5 'inde (\%15) hipotiroidi saptanmıştır. Hastaların hiçbirinde temporal lob nekrozuna rastlanmamıştı. Tedavi sonrası karotis arter stenozu, uygulanan dozdan çok tedavi sonrası geçen süreye ve hastanın aterosklerotik risk faktörlerini taşıyacağı yaş grubunda olmasına bağılır. Bu grup hastaların takip ve kontrollerinde geç toksisitenin iyi şekilde değerlendirilmesi, aterosklerotik risk faktörlerine yönelik önleyici tedbirlerin alınması ve tedavisine yönelik gerekli adımların atıması önerilmektedir.

Anahtar Kelimeler: Baş-boyun tümörü, Radyoterapi, Geç toksisite, Hipotiroidi 


\section{INTRODUCTION}

There is a high incidence of carotid artery stenosis after neck irradiation administered to patients with head and neck carcinomas. However, this issue has not drawn adequate attention from the researchers due to the short survival in this group of patients. Recent use of more efficient RT instruments in treatment units has prolonged the survival of these patients. This has led to an increased prevalence of late side effects such as carotid artery stenosis. ${ }^{1}$ While in previous studies the incidence of carotid artery stenosis after treatment was between $12 \%$ $30 \%$, this rate increased to $50 \%$ with the prolongation of the survival. ${ }^{2}$

The effect of ionizing RT on small and medium size vessels is well known since 1940s. Although the effect of treatment on large vessels such as carotid is not entirely clear, it may be narrowing vessel lumen by causing hyperplasia in intima and necrosis and fibrosis in media, increasing intima-media dimension. ${ }^{3}$ Studies suggested carotid endarterectomy over $60 \%$ carotid obstruction. For this procedure to be helpful cerebrovascular event risk must be lower than $3 \% .{ }^{4}$ However, high morbidity of surgical interventions after RT and short survival has rendered these treatment approaches controversial. On the other hand, the fact that patients will benefit from preventive treatmant is accepted by many investigators. ${ }^{5}$

Carotid stenosis is influenced by other factors such as hypertension, diabetes, smoking and obesity as well as RT. Patients at risk of carotid stenosis are recommended to be more closely monitored and evaluated with suitable imaging methods. In order to decrease this sequela of head and neck irradiation, it is important to treat hypertension and diabetes seriously and provide consultation for obesity and smoking. ${ }^{1}$ RT applied in the treatment of head and neck carcinomas frequently leads to iatrogenic hypothyroidism. Hypothyroidism due to RT was first reported in 1960s. More than 20 articles on this subject have been published so far. Biochemical hypothyroidism develops in at least $50 \%$ of the patients receiving RT to the neck region. Patients receiving neck irradiation and with thyroid stımulan hormone (TSH) values above $4.5 \mu \mathrm{IU} / \mathrm{L}$ are recommended for thyroid hormone replacement. ${ }^{6}$

\section{PATIENTS AND METHODS}

Thirty-two Patients who have received RT to the head and neck region between 1995 and 2004 because of nasopharyngeal carcinoma with their RT completed at least one year ago and with no drawbacks for cranial MRI and Doppler USG of the neck were included in the present study. This study has investigated the late side effects of RT on the carotid artery, the thyroid gland and the temporal lobe.

Smoking and drinking habits of the patients and presence of hypertension, diabetes and hypercholesterolemia were assessed in detail and recorded. All patients underwent a test consisting of a series of questions in order to evaluate the history of cerebrovascular disease in them and in their families. Patients were questioned about symptoms of thyroid dysfunction and history of stroke, and signs of temporal lobe necrosis were carefully reviewed. In addition, all patients fasted for one night and detailed blood analyses were carried out; thyroid hormones (TSH, fT3, fT4, total T3, total T4) and lipid profiles (cholesterol, triglycerides, HDL, LDL) were recorded and classified in regard to normal limits. Borders of the region where irradiation was applied and the irradiation doses of the nasopharyngeal and neck regions were recorded. Changes in the neck vessels were examined with doppler USG (Siemens Germany) using a $7 \mathrm{MHz}$ linear probe and the carotid artery imaging mode. Right and left common carotid arteries, proximal of both internal and external carotid arteries were examined by the same radiologist with the patients in supine position and their necks in extension and looking to the opposite side. Measurement of the intima-media thickness was carried out with an anterolateral approach and from the back wall with the probe head forming a right angle with the vessel. Intima-media thickness was defined as the distance between the echogenic line at the blood-intima interface and the echogenic line at the media-adventitia interface. In order to look for temporal lobe necrosis and white matter damage, cranial diffusion weighted MR was taken and the results were evaluated by the same radiologist.

The results were analyzed with the SPSS 11,5 Statistical Package. Pearson's correlation test was used for correlation analysis and Mann-Whitney $U$ test for categorical evaluation. One-Sample T test was used for comparing the carotid intima-media thickness 


\begin{tabular}{|c|c|c|c|}
\hline & \multicolumn{3}{|c|}{ Intima-media thickness } \\
\hline & Minimum & Maximum & Mean+SE \\
\hline Right a.c.com. & $0.4 \mathrm{~mm}$ & $2.7 \mathrm{~mm}$ & $0.97 \mathrm{~mm} \pm 0.09 \mathrm{~mm}$ \\
\hline Left a.c.com. & $0.4 \mathrm{~mm}$ & $2.6 \mathrm{~mm}$ & $0.97 \mathrm{~mm} \pm 0.08 \mathrm{~mm}$ \\
\hline Right a.c.ext. & $0.4 \mathrm{~mm}$ & $1.6 \mathrm{~mm}$ & $0.83 \mathrm{~mm} \pm 0.04 \mathrm{~mm}$ \\
\hline Left a.c.ext. & $0.4 \mathrm{~mm}$ & $1.5 \mathrm{~mm}$ & $0.82 \mathrm{~mm} \pm 0.04 \mathrm{~mm}$ \\
\hline Right a.c.int. & $0.4 \mathrm{~mm}$ & $2.7 \mathrm{~mm}$ & $0.94 \mathrm{~mm} \pm 0.08 \mathrm{~mm}$ \\
\hline Left a.c.int. & $0.4 \mathrm{~mm}$ & $2.6 \mathrm{~mm}$ & $0.95 \mathrm{~mm} \pm 0.08 \mathrm{~mm}$ \\
\hline
\end{tabular}

Right a.c.com $=$ Right arteria carotis communis

Left a.c.com. $=$ Left arteria carotis communis

expected from the normal population with the carotid intima-media thickness of the patients undergoing irradiation in our study.

\section{RESULTS}

Thirty-two patients undergoing head and neck irradiation because of nasopharyngeal carcinoma were included in the study. Twelve $(37.5 \%)$ patients were female and $20(62.5 \%)$ were male, and median age was 40 years ranging from 17 to 61 . Median followup after irradiation was 5.2 years, ranging from 1 year to 10 years. RT doses administered were $66-70$ Gy to the nasopharynx in all patients except for 2 patients who did not tolerate RT, 50-70 Gy to both necks (left neck median dose 60.59 Gy and right neck median dose $57.81 \mathrm{~Gy}$ ) and $50 \mathrm{~Gy}$ to the supraclavicular fossa. Twenty-three of 32 patients undergoing irradiation also received chemotherapy, while 9 did not do so. In 20 patients receiving chemotherapy, treatment started with neoadjuvant chemotherapy and after 2-4 cures RT was commenced. Eight patients received RT concomitantly with chemotherapy. All patients receiving chemotherapy were given regimens involving cisplatin. In 18 patients $(56 \%)$ there was history of smoking, in 15 (45\%) hyperlipidemia, in 3 (9\%) hypertension and in 1 (3\%) diabetes. Cerebro vascular disease history was not present in any patient. Measurement of carotid artery intima-media thicknesses did not reveal a difference between right and left carotid artery values. Vessel diameters were similar in the right and left necks (Table 1).
Table 2. Effect of the RT dose on vessel thickness

\begin{tabular}{|lllll|}
\hline & & & \multicolumn{2}{c|}{ Intima-media thickness } \\
\cline { 4 - 5 } & Dose & $\mathbf{n}$ & Mean+SE & P value \\
A.c.com. & $<60$ Gy & 19 & $1.08+0.12$ & 0.18 \\
& $>60$ Gy & 13 & $0.89+0.05$ & \\
A.c.int. & $<60$ Gy & 19 & $0.99+0.11$ & 0.47 \\
& $>60$ Gy & 13 & $0.90+0.05$ & \\
A.c.ext. & $<60$ Gy & 19 & $0.83+0.04$ & 0.78 \\
& $>60$ Gy & 13 & $0.81+0.03$ & \\
& & & & \\
\hline
\end{tabular}

A.c.com. = Arteria carotis communis

A.c.int. $=$ Arteria carotis interna

When right and left necks were evaluated together, intima-media measurements were similar at doses below $60 \mathrm{~Gy}$ and over $60 \mathrm{~Gy}$ administered to the neck Intima-media thickness was irrespective of the RT dose administered (Table 2) ( $\mathrm{p}>0.05)$.

As time after irradiation is prolonged, late effects of irradiation on the vessels are expected to increase. Our study supports this idea and intima-media thickness more than 5 years after irradiation was higher than that observed in less than 5 years. Vessel thickness of the patients whose post treatment period ranged from $<5$ years ( $\mathrm{n}=16$ patients) to $5-10$ years ( $\mathrm{n}=16$ patients) were determined to be respectively A.c.com $0.79 \mathrm{~mm}-1.15 \mathrm{~mm}(\mathrm{p}=0.003)$, A.c.int 0.78 $\mathrm{mm}-1.09 \mathrm{~mm}(\mathrm{p}=0.005)$, A.c.ext. $0.72 \mathrm{~mm}-0.91 \mathrm{~mm}$ $(\mathrm{p}=0.000)$ (Figure 1)

Because the possibility of encountering predisposing risk factors for arteriosclerosis such as hyperlipidemia, smoking and hypertension increases with patient age, the thickness of the measured vessel is also expected to increase. Likewise, in our study a positive correlation was found between patient age and intima-media thickness of the carotid arteries. Vascular thickness was found to be high in patients over 40 years $(p=0.000)$. Vascular thickness was greater in patients with elevated cholesterol values than those with normal values( $\mathrm{p}<0.005)$. Similarly, patients with a history of smoking and hypertension had thicker vessels than those without such an history. $(\mathrm{p}<0.001)$ (Table 3$)$. 


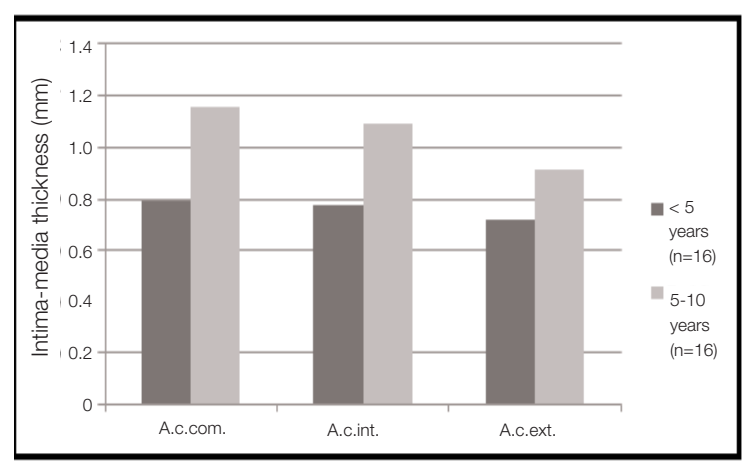

Figure 1. Effect of time after RT on vessel thickness A.c.com. $=$ Arteria carotis communis A.c.int. $=$ Arteria carotis interna A.c.ext. $=$ Arteria carotisexterna

According to the data pool with Doppler USG, carotid intima-media thickness values below $0.8 \mathrm{~mm}$ are considered normal. In our patient group, common carotid artery thickness was found to be over the average value of community in $48 \%$ of common carotid arteries, $40 \%$ of internal carotid arteries and $39 \%$ of extrenal carotid arteries (>0.8 mm). While the difference in intima-media thickness of common ve internal carotid arteries was found to be statistically significant $(\mathrm{p}<0.05)$, the difference in external carotid artery was not significant.

One of the late side effects of neck radiotherapy is hypothyroiditis. In measurements, TSH value was found to be over $4.2 \mu \mathrm{lU} / \mathrm{mL}$, which is considered the upper limit of normal, in $5(15.6 \%)$ patients.. TSH was found to be high and fT3 and fT4 normal in 3 asymptomatic patients whereas TSH was high, dT3 normal and fT4 low in 2 symptomatic patients. In five patients whose TSH values were high, hormon treatment was initiated. Patients with cranial base involvement are at risk for temporal lobe necrosis, because they are treated with a larger area of irradiation. In our study group 5 patients had cranial base involvement. None of our patients had the clinical features of temporal lobe necrosis such as vertigo, tendency to sleep, memory disorders, personality changes, epileptic seizures, deterioration of intelligence, changes in consciousness and increased intracranial pressure symptoms. None of the patients had signs of temporal lobe necrosis, white matter damage or edema in any of the diffusion weighted MR images.

\begin{tabular}{|c|c|c|c|}
\hline \multirow[b]{2}{*}{ Age } & \multicolumn{3}{|c|}{ Intima-Media Thickness (Mean+SE) } \\
\hline & $<40$ years & $>40$ years & $P$ value \\
\hline A.c.com. & $0.71+0.03$ & $1.14+0.08$ & 0.000 \\
\hline A.c.int. & $0.72+0.04$ & $1.09+0.08$ & 0.000 \\
\hline A.c.ext. & $0.69+0.02$ & $0.90+0.03$ & 0.000 \\
\hline Cholesterol & low & high & \\
\hline A.c.com. & $0.84+0.04$ & $1.28+0.15$ & 0.002 \\
\hline A.c.int. & $0.84+0.04$ & $1.21+0.15$ & 0.005 \\
\hline A.c.ext. & $0.77+0.02$ & $0.93+0.04$ & 0.002 \\
\hline Smoking & No & Yes & \\
\hline A.c.com. & $0.82+0.07$ & $1.08+0.08$ & 0.001 \\
\hline A.c.int. & $0.73+0.04$ & $1.10+0.08$ & 0.000 \\
\hline A.c.ext. & $0.70+0.02$ & $0.91+0.03$ & 0.000 \\
\hline \multicolumn{2}{|c|}{ Hypertension No } & Yes & \\
\hline A.c.com. & $0.86+0.04$ & $1.96+0.29$ & 0.000 \\
\hline A.c.int. & $0.84+0.03$ & $1.86+0.24$ & 0.000 \\
\hline A.c.ext. & $0.77+0.01$ & $1.30+0.10$ & 0.000 \\
\hline
\end{tabular}

A.c.com. $=$ Arteria carotis communis; A.c.int. $=$ Arteria carotis interna A.c.ext. $=$ Arteria carotisexterna

\section{DISCUSSION}

Irradiation is the main treatment modality in nasopharyngeal carcinomas. Because long survival can be obtained in nasopharyngeal carcinoma, late side effects of the treatment have a special importance. Effects of head and neck irradiation on oral dental health, salivary glands and skin-subcutaneous tissues are well known. However, effects on the vessels, thyroid gland and temporal lobe have not been adequately investigated. Data obtained from people exposed to low dose radiation have demonstrated that vascular damage does not develop. However, these doses are far below those used in RT. Therefore, it is accepted that vessel injury occurs at treatment doses. Elerding et al. have carried out carotid angiography on Hodgkin's lymphoma patients at the mean age of 28 years and who underwent irradiation at least 5 years ago, and have found vascular changes at a rate of $22 \%$. These findings show that vascular changes can occur even in a patient group who 
receive a relatively low radiation dose such as those with Hodgkin's lymphoma.? Although vessel injury secondary to RT has been established, threshold value of the relation between dose and injury has not been determined so far. Chung et al. ${ }^{8}$, have compared patients receiving high dose irradiation ( $65 \mathrm{~Gy}$ ) with those receiving lower doses $(<60 \mathrm{~Gy})$, and could not establish a dose related relationship with the intensity of carotid changes in post-irradiation MR angiography studies. Also in our study, a dose-response relationship could not be shown in patients receiving 50-59 Gy dose and those receiving 60-70 Gy dose. Experimental and clinical studies show that changes in small vessels begin in a shorter time, while those in large vessels are observed at a later stage. In order to make a diagnosis and prevent untoward side effects before occurring, we should determine when the vascular damage develops after irradiation. Muzaffar et al. have found that progressive increase in intima-media thickness occurs during the first 2 years after irradiation. ${ }^{9}$ Other authors have also shown that severe carotid stenosis occurs at a high rate of $22 \%$ during the first 5 years following irradiation. ${ }^{10}$ In contrast to these clinical studies , Cheng et al. ${ }^{11}$ have found that the time for the development of stenosis after irradiation is longer (longer than 5 years). Also in our study, intima-media thickness of the patients with more than 5 years after irradiation was statistically significantly greater than those with less than 5 years.

In the study on vascular changes in the normal patient group conducted by Belcaro, a relationship between patient age and atherosclerotic changes was determined. It was seen that changes in carotid become more marked with advancing age. In another study similar to that of Belcaro vascular changes were present in $13 \%$ between 20-29 years and in $64 \%$ between $30-39$ years. In the present study, it was found that thickness of the carotid-intima media increases significantly with age. Hypertension, hypercholesterolemia and smoking are risk factors for increased intima-media thickness in adults above 40 years and undergoing irradiation. Lamberts and Boer have shown in their study on rabbits with high cholesterol undergoing a low dose of X-ray such as 5 Gy that some changes occur in the carotid. They have stated that while the lipids in the blood circulation diffuse into the vessel wall, the lipophages form a precipitate..$^{12}$ In another study, Tiamson et al. have administered 6 Gy radiotherapy to rabbit aorta, and have found more extensive atherosclerotic changes in the rabbits under high cholesterol diet than the control group..$^{13}$ In the present study, age above 40 years, smoking, hypertension, high levels of cholesterol were found to be statistically significant risk factors. Increased intima-media thickness was found at a higher rate in patients with these risk factors. The most frequent finding seen after irradiation of the thyroid gland is hypothyroidism. ${ }^{14}$ Hypothyroidism occurs when the dose of radiation received by the thyroid gland exceeds 26 Gy. Hypothyroidism is either apparent or in the form of sub-clinical hypothyroidism (abnormal elevation in serum TSH and normal serum fT4). Studies have reported the incidence of hypothyroidism as a result of neck irradiation to show a wide variation between $3 \%$ and $92 \%$ but it was in the $20 \%-30 \%$ range in the majprity. ${ }^{15}$ In our study, hypothyroidism was seen in 5 of 32 $(15 \%)$ patients. The lower rate of hypothyroidism in our study may be due to the fact that entire thyroid lobe was not included in the treatment volume.Temporal lobe necrosis following treatment for nasopharyngeal carcinoma is a serious late side effect. The incidence of temporal lobe necrosis depends on different variables such as total irradiation dose applied, irradiated brain volume and treatment duration. ${ }^{16}$ Lee et al. ${ }^{17}$ have found temporal lobe necrosis in $3 \%$, and white matter damage in $1 \%$ of patients receiving 65 Gy radiotherapy to the nasopharynx. In another study $^{18}$, fifty-four of 849 patients showed radiological changes of temporal lobe necrosis. There were mild symptoms (vertigo, tendency to sleep, memory disorders, and personality changes) in 50 patients and severe symptoms (epileptic seizures, deterioration of intelligence, changes in consciousness) in 4 . None of our patients had radiological changes pertaining to temporal lobe necrosis and white matter damage.

\section{Conclusion}

Because of improvement in survival in head-neck cancer patients in recent years, quality of life has become importent. During follow in this group of patients, Doppler USG for vascular occlusion evaluation and thyroid fonctions tests for hypothyroidism should be performed at least annually. When patients develop symptoms of temporal lobe necrosis, it should be to be examined with diffusion weighted 
MR images. Prophylactic measures are suggested for such pathologies and they shoudl be trated judiciously when necessary.

\section{REFERENCES}

1. Obayami OK. Neck irradiation, carotid injury and its consequences. Oral Oncol 40: 872-878, 2004.

2. Moritz MW, Higgins RF, Jacobs JR. Duplex imaging and incidence of carotid radiation injury after highdose radiotherapy for tumors of the head and neck. Arch Surg 125: 1181-1183, 1990.

3. Murros KE, Toole JF. The effect of radiation on carotid arteries: a review article. Arch Neurol 46: 449-455, 1989.

4. Executive Committee for the Asymptomatic Carotid Atherosclerosis Study. Endarterectomy for asymptomatic carotid artery stenosis. JAMA 273: 14211428, 1995.

5. Cheng SW, Ting AC, Wu LL. Ultrasonic analysis of plaque characteristics and intimal-medial thickness in radiation-induced atherosclerotic carotid arteries. Eur J Vasc Endovasc Surg 24: 499-504, 2002.

6. Garcia-Serra A, Amdur RJ, Morris CG, et al. Thyroid function should be monitored following radiotherapy to the low neck. Am J Clin Oncol 28: 255-258, 2005.

7. Elerding SC, Fernandez RC, Grotta RC. Carotid artery disease following external cervical irradiation. Ann. Surgery 194: 609-615, 1981.

8. Chung TS, Yousem DM, Lexa FJ, et al. MRI of carotid angiopathy after therapeutic radiation. J Comput Assist Tomogr 18: 533-538, 1994.

9. Muzaffar K, Collins SL, Labropoulos N, et al. A prospective study of the effects of irradiation on the carotid artery. Laryngoscope 110: 1811-1814, 2000.

10. Carmody BJ, Arora S, Avena R, et al. Accelerated carotid artery disease after high dose head and neck radiotherapy: is there a role for routine carotid duplex surveillance. J Vasc Surg 30: 1045-1051, 1999.

11. Cheng SWK, Wu LLH, Ting ACW, et al. Irradiation-induced extracranial carotid stenosis in patients with head and neck malignancies. Am J Surg 178: 323328, 1999.

12. Lamberts HD, de Boer GM. X-ray induced atheroma lesions in the arterial wall of cholesterolemic rabbits. Int J Radiat Biol 165-174, 1967.
13. Tiamson E, Fritz KE, Campana H, et al. Studies in rabbits of cellular mechanisms accounting for enhancement of diet-induced atherosclerosis by $\mathrm{x}$-radiation. Exp Mol Pathol 12: 175-184, 1970.

14. Grande C. Hypothyroidism following radiotherapy for head and neck cancer: Multivariate analysis of risk factors. Radiother Oncol 25: 31-36, 1992.

15. Thorp MA, Levitt NS, Mortimore S, Isaacs S. Parathyroid and thyroid function five years after treatment of laryngeal and hypopharyngeal carcinoma. Clin Otolaryngol 24: 104-108, 1999.

16. Buchpiguel CA, Alavi JB, Alavi A, et al. PET versus SPECT in distinquishing radiation necrosis from tumor recurrence in the brain. J Nucl Med 36: 159-164, 1995.

17. Lee A, Poon Y, Foo W, et al. Retrospective analysis of patients with nasopharyngeal carcinoma treated during 1976-1985: Survival after local recurrence. Int Radiat Oncol Biol Phys 26: 773-782, 1993.

18. Shyn-an Yeh, Yeh Tang, Chun-Chung Lul, et al. Treatment outcomes and late complication of 849 patient with nasopharyngeal carcinoma treated with radiotherapy alone. Int. J. Radiation Oncology Biol Phys 62: 672-679, 2005.

\section{Correspondence}

Dr. YIImaz TEZCAN

Selçuk Üniversitesi Meram Tıp Fakültesi

Radyasyon Onkolojisi Anabilim Dalı

KONYA / TURKEY

Tel: (+90.312) 0.332. 2236942

e-mail: yilmaztezcan@yahoo.com 